\title{
The Influence of Administrative Procedure of Online Registration of Job Seekers to The Effectiveness of a Yellow Card on The Department of Employment Cianjur District
}

\author{
${ }^{1}$ Ira Septira Aripin, Tias Safira Handayani, Wilma Zuarko Adji
}

${ }^{1}$ Politeknik Piksi Ganesha, Indonesia; isaripin@piksi.ac.id

Received: July 3, 2021; In Revised: November 8, 2021; Accepted: December 11, 2021

\begin{abstract}
Department of employment Cianjur District is a government agency that provides yellow cardmaking services using online administration procedures. The public is required to rule the technology that is constantly changing. The research aimed to find the effectiveness of making a yellow card online compared to making a yellow card offline. Finding how much to improve the service quality of the yellow card making online is the primary goal in the policy. The writer does the research using descriptive analysis. The research was ducted against yellow card makers and employees of the department of employment Cianjurdistrictk, the technique of data collection used with observation, documentation, the written interview also literature review, which has a close relationship with the subject matter, the data is processed using descriptive analysis.From this research, the result is that yellow card making online $99 \%$ can be adequate time and the cost also makes it easier for the public making the yellow card.
\end{abstract}

Keywords: Procedure, Administration, Registration, Effectiveness, Yellow Card

\section{Introduction}

In today's digital era, the internet is needed in various fields. One field service is the public sector. The government continues to provide fast service to find solutions for the people, especially job seekers. However, the community has been very selective in determining the choice and demands of what are to be their rights, would not want the government as a public service to provide quality service, and does not rule out what became of the rights of the community itself. Therefore, local governments were required to provide services and a more accessible community. However, the services provided are impressed less responsive, so that often take quite a long time so give a bad stigma to the public related to the services performed by the department concerned, especially the Department of Employment Cianjur district. In this case, the effectiveness in the public service is simple yet very needed at the local level because of the direct services at the regional level aimed at the community so that people can feel the quality of services provided.

Government officials' lack of public services gives the impression of bad governments around the community. Some people who had been in contact with the bureaucracy often mind and are not satisfied with the service provided. Several people still look down on the performance of the bureaucracy. Finally, most of the service users or the public are looking for a quick way to use the services of brokers to manage his need related to government 
bureaucracy (Damayanti, Suwena, \& Haris, 2019). The service provided by the bureaucracy of the government in Indonesia is something of a general nature also had frequent events, namely the slow and convoluted in the completion of the administration of an interest. If desirous of obtaining maximum service, the community should carry out the remuneration (feedback) with pay according to the amount specified. Then it belongs to the bribery section and is typically ensured included in acts of corruption, collusion and nepotism (KKN). This means that the service is dissatisfied. It makes people not interested in directly managing the bureaucracy (Suandi, 2019). To achieve these objectives, every company or organization should have each administration in every division, making labour more effective. Administration, namely a series of activities that should be developed sustainably, the Administration also as one of the tools to achieve the goal that earnest could give an essential role for all agencies in terms of public services, companies and organizations must be able to analyze and convey information where such activities related to administrative procedures.

Simple administrative procedures make it easier for all parties, not only the public. Procedure administration also facilitates internal control, guarantees the uniformity and alignment between the data provided by both parties, and enables public service documenting the activities that routinely occur in an agency of the government in making a yellow card. However, the purpose that you want to accomplish to provide services and the demands that the people wanted less goes well. Lately, a lot of obstacles that the government apparatus must pass, especially the Department of Employment Cianjur district, from the lack of experts in a related field, less organized communities are coming, as well as the lack of socialization of officers in providing services in the making of a yellow card.

Therefore, the Department of Employment Cianjur district provides services in simple but quick, presenting the service of a yellow card online, supported with the internet that anyone can reach anytime and anywhere. Concerning the service of making the yellow card, the Department of Employment Cianjur district has implemented a policy of running administrative services online through the medium of support services to be more optimal and easier for people who need a yellow card in which such a document is a requirement of applying for a job in a private company or government agencies. Efforts and policies of this be an advantage for people who want to make the yellow card. People have no difficulty executing a yellow card, given Cianjur district is one of the regions constrained access to the centre of the city where the head office of the Department of Employment operates. Society simply accesses through your smartphone and wait for the next day to capture the card without having to queue that will be less conducive to his service in the office of Employment Cianjur district.

According to Mulyadi, cited by (Wijaya \& Irawan, 2018), the Procedure means "a series of activities of clerical (writing, duplicate, assess, compare between the data source with the data supporting all parties). Often hooking up some people at the ministry and more, which is necessary in order to endure the handling of the uniformly corporate transactions that take place many times". According to Tambunan cited by (Arifani, 2016) the procedure is "as the guidelines which contain the provisions of the operations contained in an organization that is used to assure that all the assessment, treatment, and usage of the facilities of the process carried out by several people in the organization who is a member of the organization run effectively and efficiently, the desired consistency seen, the standard also systematically". According to Ismail Mashallah cited by (Rahastine, Mayasari, \& Sasmita, 2019) argue that the procedure is a series of tasks that are interrelated and regulated by the order and procedures of particular deliberately created or planned to facilitate the implementation of the work that is done repeatedly. According to Susanto, cited by (Shinta Dwi Prana Dewi, Moch Dzulkirom, 2015), 
The procedure is the activity or activities performed over and over again the same way. According to Sutabri, cited by (Rahastine et al., 2019) concluded that, "the Procedure is a sequence of clerical activity. The activities of clerical done to record the information in the form, book journal, and the ledger, the activity consists of writing activities, duplicate, enumerate, give the code, register, select, move, and compare." From some of the opinions above, it can be concluded that the Procedure is a grammar how to meet a requirement in order to be eligible activity.

According to Kamaluddin cited by (Trivena, Wijayanti, \& Evelina, 2019), "the administration is typically only associated with the administration's activities that contain correspondence, secretarial, the preparation of the report as well as archive". According to Ordway-Tead cited by (full Moon, Harjoyo, \& Salam, 2020) "the administrative load of activities that must be implemented by the executive in the organization of the role that is set up, promote, set a complete the cooperative effort of a group of people that met in a special order to get a certain goal." According to Leonard D. White cited by (Purnama et al., 2020) "administration is a process that is usually found in all companies in the group, whether government or private, civil or military, big or small". According to Koto Banga cited by (Hadiaty \& Handayani, 2018) "administrasi in the narrow sense, namely activities that are administrative, which contains correspondence, starting from a recording or a list of incoming mail is also outgoing mail, typing, copying, distribution, and archiving, including the recording management data and information needed by the leader for the determination of policy and decision-making related to the duties and functions of the organization". According to Silalahi, cited by (Marliani, 2018) Administration in a broad sense is defined as cooperation. The term administration is associated with cooperation activities carried out by humans or people to reach the desired goal. Cooperation is a series of activities carried out by a group of people together, organized and directed by the division of tasks in accordance with the collective agreement.

According to Beni, cited by (Sartika 2019), effectiveness is "the relationship between output with the purpose or can be said to be a measure of the extent to which the level of output, the policies and procedures of the organization. The effectiveness is also related to the degree of success of an operation in the field of the community. An activity is said to be effective if the activity has a huge impact on the ability to provide public services, which is the target that has been determined. The higher the effectiveness ratio, the better the performance of local government. Effectiveness means the utilization of resources, the means also of infrastructure on the specific amount that was decided earlier to produce or services activity that he does". According to a Prosperous cited by (Bonso \& Lawelai, 2020) suggests the perspective of the effectiveness of the actual sourced from one of the benchmarks of administrative sciences, which grows naturally into a diverse range of human activities in order to achieve the desired goal.

According to Mahmuin, cited by (Megawati, 2019) the effectiveness of a program can be seen from indicators program or plan. If all the projects can be done, the program declared effective, Indicators, functions and duties. The institution was declared effective if it could perform the function also his job. With another term, a draft of the learning will be adequate if the task, as well as protective a, can be done with sound, condition Indicator ideal or goal, which was declared sufficient a draft if the draft from the results can be obtained purposes or conditions ideally, Indicators, regulations, and provisions, function or whether or not a rule can determine the effectiveness of a design is in protecting the sustainability of the process of the activity. According to Schemerhorn cited by (Kiwang, Pandie, \& Gana, 2015), Effectiveness 
is the achievement of the target output is measured by comparing the output of the budget or is supposed to output the realization or, indeed, said to be effective if the work should be more excellent than the output truth. According to James L. Gibson, cited by (Marliani, 2018) said that the effectiveness is the achievement of the objectives of the joint efforts. According to Setianto, cited by (Sukirman, Rosmiati, Alam, \& Kamal, 2020), the yellow Card (AK.1) is intended for job seekers. This card is used as a database for Depnakertrans / Department of Employment local to measure the percentage of job seekers in its territory. According to Hamria cited by (Sukirman et al., 2020), AK.1, commonly known as the yellow card, is a card used by job seekers to describe that they haven't and are looking for work. This card shaped plain paper with white colour plain contains the identity of the job seekers. Formally this card is named AK1 stands between work, managing data, identity card number, and being legalized by the Department of Employment. The manufacture of AK.1 is necessary because the job applicants can easily complement job application files.

The purpose of this research is to explain and find out how practical making yellow cards online than with making a yellow card offline and find out how significant the improvement of the quality of service making yellow cards online, as well as whether the manufacture of yellow cards online can facilitate the community or just complicate its course becomes the main objective in this policy.

\section{Methods}

The method used in this research is the descriptive method with a qualitative approach. The authors explain and describe the subject of this research from data collection and data analysis. In this method, the authors directly observe the work and data collection processes using several techniques, such as the observation method. For example, the authors observed the working process when making a yellow card at the Department of Employment Cianjur district. Documentation method, where the authors collect data from materials that load written information or pictures in the Department Employment Cianjur district. The interview method, where the authors interviewed the respondents or interviewees directly to collect information. And the literature review method, authors collect data and information through electronic documents written that could support the research process.

\section{Results and Discussion}

In this section, the researcher will analyze some of the research data obtained, how the influence of registration administration online a yellow card on the effectiveness of the manufacture of a yellow card at the Department of Employment Cianjur district. Department of Employment Cianjur district is one government agency where the services associated with the yellow card with the online system. According to Effendy, cited by (Nurjanah, 2020), the effectiveness of a communication process to reach the goal, which is prepared in accordance with fencing's cost, the time specified, and the number of workers, is determined.

The definition of effectiveness according to KBBI that there is the effect, effective, productive, can bring results, succeed to and begin to apply. Application registration online administration, which is a progress of policies applied to the Disnaker Cianjur district, was in line with the development of technology so that it can be easier and saves time for the people to obtain information in this regard the making of a yellow card. According to Edy Sutrisno, cited by (Sukmasari, 2018) about the variables that influence the organization of the 
effectiveness of that technology. Based on interviews that have been done to the 35 samples of making a yellow card obtained the data that the manufacture of a yellow card by using the procedure of registration in online make effective.

Technology is a work that transforms the input into output, goods or services. The strategy used party Disnaker Cianjur district, so this new program goes well and smoothly is (1) the addition of computer facilities in the service to manage and check the data community that has been previously successfully registered, (2) paste and share more information through print and electronic media how the procedure for the use and services in the online system (3) add labour experts in the field of informatics particular deal-making site a yellow card if an error occurs or maintenance, (4) routine every morning to give direction to the people who came about the procedure of making a yellow card online. According to P. Robinson Stephen, cited by (Sukmasari, 2018), effectiveness is doing the activity that directly supports the organization to achieve various objectives.

The procedure is a series to run a process. Where contains the stages of activity in a process done by a person in charge of it explains how to do it. Disnaker Cianjur district issued a policy about making a yellow card where registration administration implemented online. The policy is enforced from the start of 2019 and intensively informs society of using electronic media and print in the paste around Disnaker Cianjur district. The announcement contains information for people who want to make the yellow card to access the web provided by Disnaker. It will be guided to create an account and a password for the user in quality and input data in the next stage. Registration administration online a yellow card on the Disnaker Cianjur district, between the form of services to the community provided by Disnaker Cianjur district for the community to earn yellow card issued by Disnaker as well as facilitate service to run conducive. In addition to the Registration administration online, the yellow card site Disnaker also has a lot of options in providing the information needed by the community, particularly job seekers. In between his issuance of a yellow card, the Approval of the Establishment of the Labor market Special (BKK), Report the Existence of Kerja (TPP), the Issuance of Recommendations Exteang IMTA, to permit the establishment of LPTKS, recommendation Passport CTKI, the Field of Industrial Relations and social security, as well as info job opportunities and the training can be followed by the public for free. Following the registration steps, the administration of the online yellow cards:

Figure 1

\section{Access Registration Administration Online Yellow Cards}

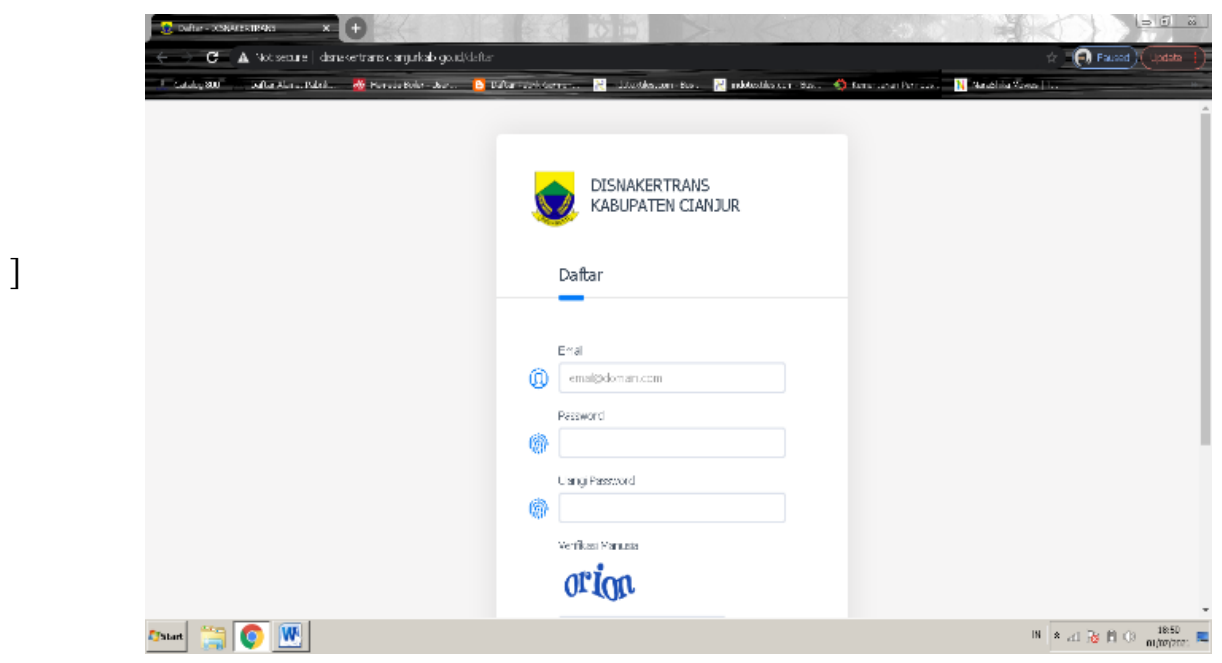


]Source: Disnaker Cianjur district, 2021

The image above is the first display in the site Disnaker Cianjur district. Users must have the email/username first, create a password and input the code capta to access registration online more. To get access through email/username, the user is directed to fill the first biographical data to fill the data such as NIK, full name, place of birth, date of birth, gender, religion, nationality, education, department, year of graduation, name of the college/school, degree, marital status, physical state, domicile and phone number users that will register.

Figure 2

\section{Login Access Making Yellow Card}

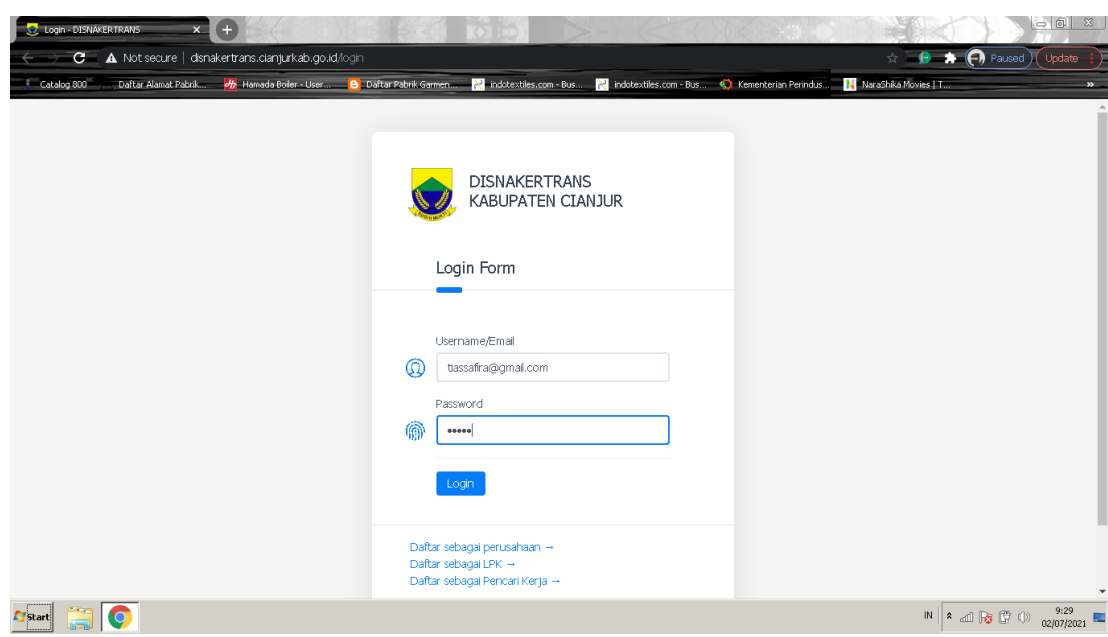

Source: Disnaker Cianjur district, 2021

Data entry details, email/username and password that we already created earlier will be instantly verified. Then, the user is guided to $\log$ in with the re-enter email/username and password that this in the register on the first stage was, once filled with the appropriate further direct users to click on the word login to continue the next step.

Figure 3

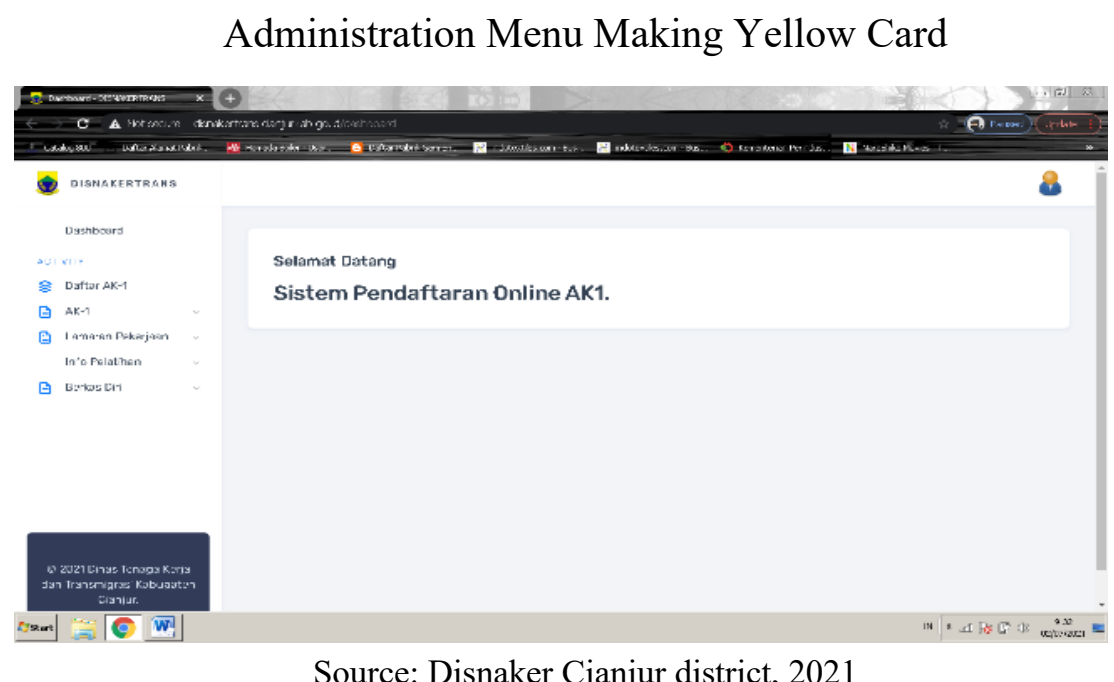

The image above is the initial display of the site making a yellow card. Presented with the appearance of saying "Welcome to the Online Registration System AK1" next, the user is 
Publica: Jurnal Pemikiran Administrasi Negara

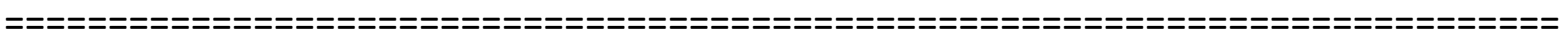

directed to click on the list of AK-1 in the left part of the page to complete registration to the next stage.

Figure 4

Input Data Making Yellow Card

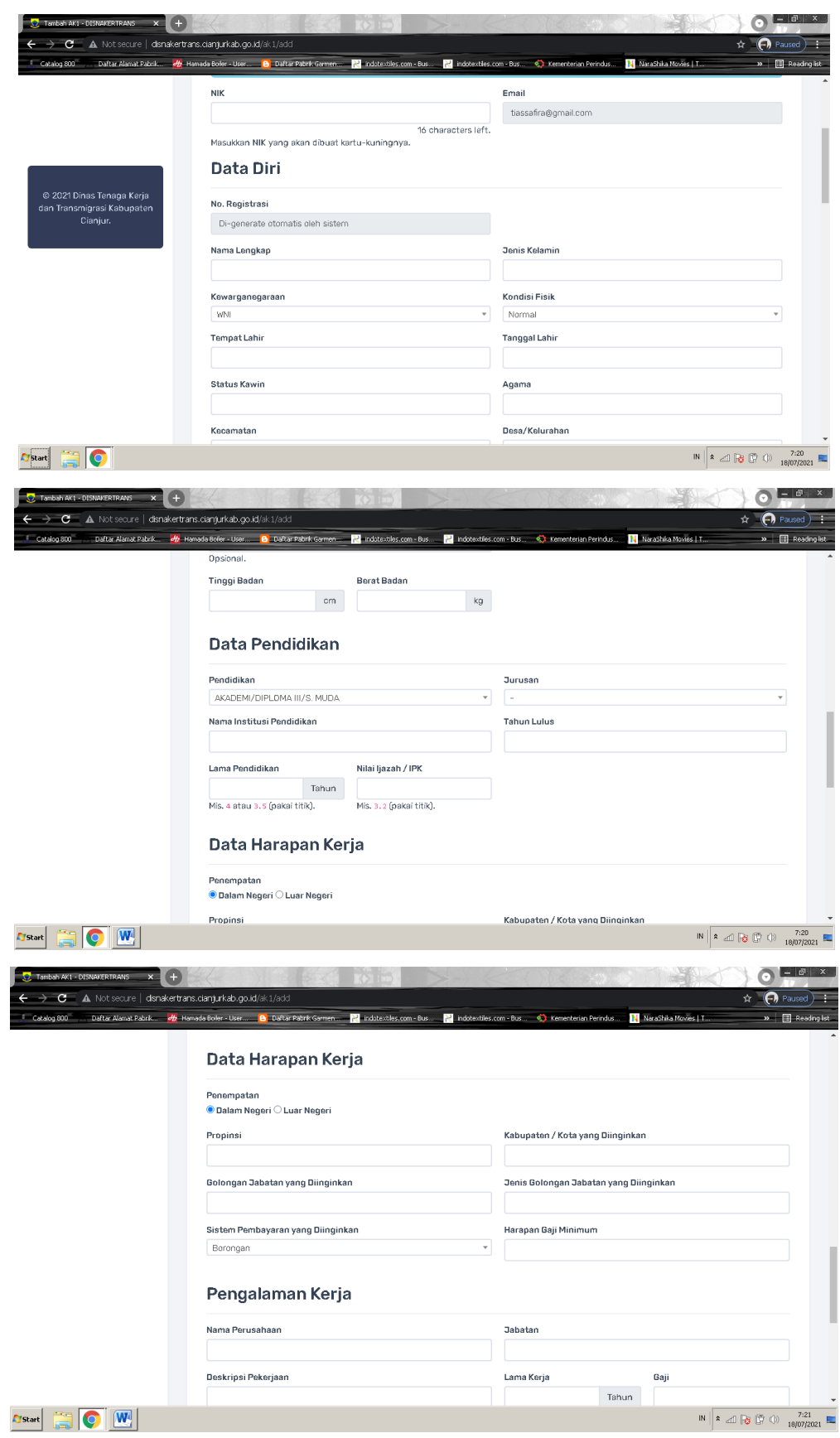




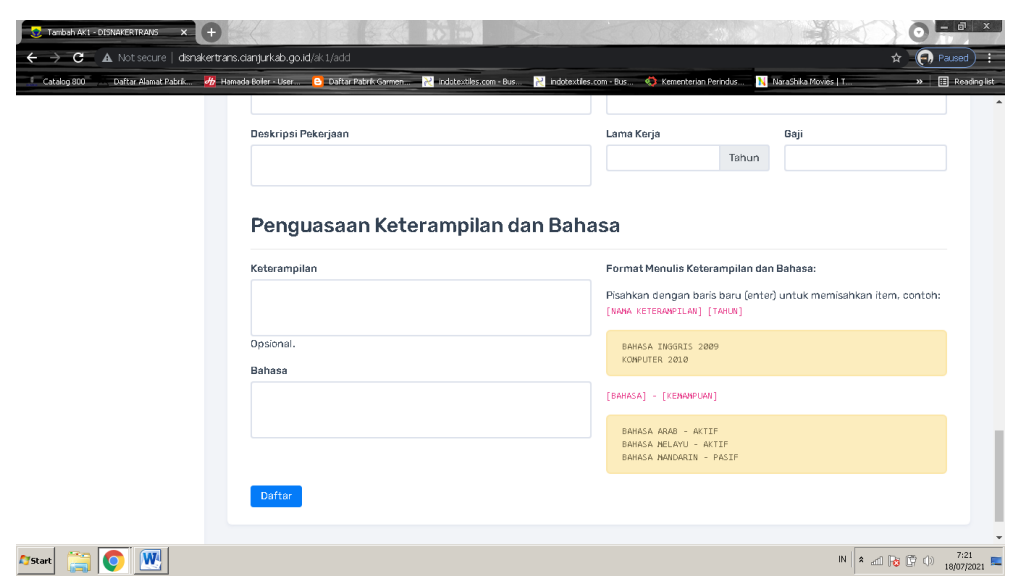

Source: Disnaker Cianjur district, 2021

The above picture card maker yellow redirected to fill out the corresponding complete ID card maker in between, NIK, full name, address, gender, education data, data work expectations, work experience if it was previously maker yellow card never worked in a company or government agency, as well as the mastery of a foreign language and Indonesian, which controlled by the maker in order to become an added value for the manufacture of a yellow card if you will be applying for a job in a private companies sector and government agencies.

Figure 5

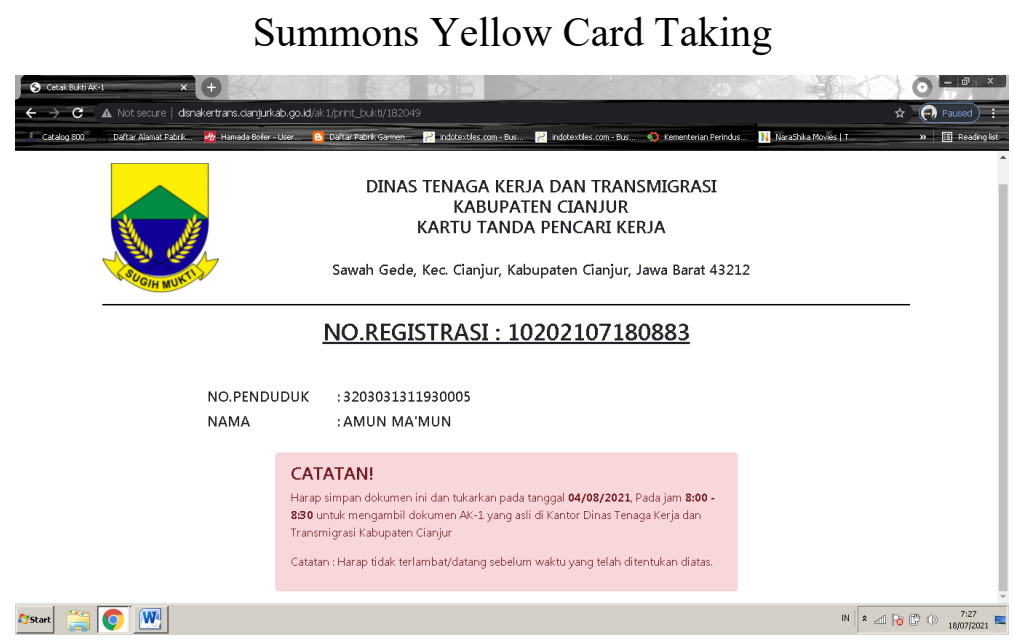

Source: Disnaker Cianjur district, 2021

At this stage, the maker should print the call letter that contains the day and hour of taking a yellow card. A later letter must be presented to the employee Manpower as evidence that the maker has completed phase registration online and mail order to be exchanged with a yellow card. Following the results of research on the effectiveness of a yellow card based on the opinion of the respondents obtained from the measurements quantitatively over the administrative procedure of making a yellow card on the Department of Employment Cianjur district available information as follows:

Before the enactment of the making of yellow cards online, the Department of Employment Cianjur district in serving to make yellow cards using the method of offline where people register manually and come directly to the office of the Disnaker with bringing a file has been specified, the absence of a restriction on the manufacture of yellow cards every day resulted in the community to come crowding meet the office of Manpower. The registrant can 
reach 6,000 every six months with the achievements of yellow cards that are resolved timely, namely 4.200. The community to come in the morning to wait in line, hoping they get queue most front and get a yellow card as soon as possible. There are some constraints experienced by Manpower in the service of a yellow card offline. These constraints occur not only in the community but also from employees of Manpower own particular serving making a yellow card, including:

1. The buildup of the file resulted in many files being scattered so that the absence of certainty for community to get a yellow card as soon as possible.

2. Many people who come lead work piled up and often occur by human error due to incorrect input of data by employees of Manpower.

3. Cutting off recess employees due to the many people who want to be served quickly and result in the employee Manpower having to go home late at night to finish the job.

With the minister's decision and the circular letter of the regent about the presence of PPKM (Imposition of Restrictions on the Activities of the Society), which was previously called with the PSBB (Restriction of Large-Scale Social) in the current situation of the pandemic covid-19, then making a yellow card was done online restricted with an average of applicants, namely the 1,800 applicants every six months with the achievements of yellow cards that are resolved timely namely 1.782 . By this policy, the manufacture of yellow cards online became more organized with better although the number of applicants more on when offline, the level of achievement in terms of time speed and precision of the manufacture of a yellow card has increased very well. However, seen from the comparison is visible if the administrative procedure of registration of job seekers that are made offline are not conducive because of his many applicants who come in and done manually enable the mismatch of data that will be inputted, will also be working less, so that takes more time so that the resulting inaccuracy of the time of the completion of the manufacture of a yellow card.

While on registration with the way the online system of the Department of Employment Cianjur district is one of the agencies that have the portal service online with the name of the site workforce.cianjurkab.go.id created with the aim as one of the means of assistance for needed by society to help minimize data entry errors because the applicants can enter the data of his own and after that just need to print it without having to wait, it is beneficial in terms of time efficiency. For the way data entry online is effortless to understand, given to the times now-based administration online is no stranger for the people. But sometimes, the technology experiences maintenance that has to be renewed from time to time for the website or application in a state that is most excellent so that applicants can access a website smoothly without any obstacles.

Based on interview research got the information if Disnaker still has a shortage of human resources experts who handle mainly if the site Manpower in case of error, in terms of facilities available web by the office of Manpower is inadequate, so that people complain it is challenging to access the web, the online system less smoothly, which resulted in the community must come directly confirm these constraints to the office of Manpower and caused so much time wasted, in addition to serving the making of a yellow card, the employee should also be directing the community to come if the web Manpower is being impaired, such events can happen. As a result, many people the access to and impact on the less smooth web is provided by Manpower. 
In terms of cost, registration with the system offline may require the cost of transportation for the registrant to go to the office of the Department of Employment to take care of the administration of registration card making yellow. And on the online registration only with network internet. Applicants can visit the website of the official Department of Employment Cianjur district, which can be accessed from Monday to Friday from 07.00 PM till 4:00 PM.

For factors that influence the administrative procedure of online registration a yellow card, the author cites the opinion According to Gibson Ivancevich Donelly cited by (Sukmasari, 2018) between the measure of the effectiveness of the organization, namely the satisfaction to showing the level at which the organization can meet the needs of the community. The elements are interconnected and essentially confirmed in terms of human resources (employees), facilities, and time.

\section{Conclusion}

Based on the results of research and discussion that has been made can be concluded that the perception of the registrar of job seekers over the administrative procedure of online registration of job seekers on the effectiveness of the manufacture of a yellow card on the Department of Employment Cianjur district that registration with the way the online system is more effective in terms of time cost and accuracy of data. The Department Of Employment Cianjur district, utilizing the facilities and infrastructure technology, can carry out the duties and functions of his good program that runs smoothly in accordance with its objectives, which give service online registration. The administration of the online registration job seeker can help people who want to make a yellow card in the pandemic covid-19. The effects of variations in registration are apparent through the online system. If percentage to effectiveness making a yellow card for offline $70 \%$, while for the making through the online system to effectiveness percentage of $99 \%$ was not spared from the possibility of things beyond expectations. 


\section{References}

Arifani, R. (2016). The Procedure For Payment Of Premiums For Policyholders Of Life Insurance Bersama ( Ajb ) Bumiputera 1912 Kantor Marketing Agency Tunjungan Surabaya. Surabaya. Retrieved from http://repository.unair.ac.id/55569/.

Bonso, H., \& Lawelai, H. (2020). The Effectiveness Of The Manufacture Of A Special Regulation In The Province Of Papua: A Study Of The Papuan People's Assembly. Journal Of The Governance Studies, 1(2), 30-45. Retrieved from https://scholar.google.co.id/citations?view_op=view_citation\&hl=id\&user=1O5FrWEA AAAJ\&citation_for_view=1O5FrWEAAAAJ:2osOgNQ5qMEC

Damayanti, L. D., Suwena, K. R., \& Harris, I. A. (2019). The Analysis Of Public Satisfaction With Public Services Based On The Community Satisfaction Index (Ikm) The Office Of The District Of Sawan, Buleleng Regency. Journal Of Economic Education Undiksha, 11(1), 21. https://doi.org/10.23887/jjpe.v11i1.20048

Hadiaty, F., \& Handayani, R. F. (2018). Administrative procedures Sales of Motor Vehicles In the Admin Section In PD Wijaya Abadi Bandung. Journal LPKIA, XI(2), 1-6. Retrieved from http://jurnal.lpkia.ac.id/index.php/jkb/article/view/211

Kiwang, A. S., Pandie, D. B. W., \& Gana, F. (2015). Policy analysis and the Effectiveness of the Organization. JKAP (Jurnal Policy And Public Administration), 19(1), 71. https://doi.org/10.22146/jkap.7535

Marliani, L. (2018). The Definition Of Administration In Various Angles. Dynamics : The Scientific Journal of The State Administration, 5. Retrieved from https://jurnal.unigal.ac.id/index.php/dinamika/article/view/1743/1407

Megawati. (2019). The effectiveness of Integrated Services In the Licensing Erect the Building in Order to Realize the Quality of Public Services in the District of Sinjai (Vol. 1). Makassar. https://doi.org/10.1088/1751-8113/44/8/085201

Nurjanah, N. (2020). The Effectiveness Of The Service Card Is A Sign Of A Job Seeker At The Department Of Labor Blitar According To The Islamic Perspective. Tulungagung. Retrieved from http://repo.iain-tulungagung.ac.id/16895/.

Full Moon, D. D., Harjoyo, \& Salam, A. (2020). The Procedure Of Administration Of Services Of Delivery Of Goods At Pt Citra Van Titipan Kilat Tangerang. The Scientific Journal Science Secretary/Office Administration, 7(1), 1. https://doi.org/10.32493/skr.v7i1.4570

Rahastine, M. P., Mayasari, S., \& Sasmita, N. (2019). The Strategy Of Public Relations Of Pt Indotama Works Brilliantly In Improving The Understanding Of The Procedural Process Of Indonesian Workers. Horizon - Journal Of The Humanities, 19(2), 237-242. https://doi.org/10.31294/jc.v19i2.6487

Sartika, D. (2019). Analysis Of The Effectiveness Of Income Levies In Increasing The Revenue Of The City Of Palembang. Universitas Muhammadiyah Palembang, 11. Retrieved from http://repository.um-palembang.ac.id/id/eprint/5337/

Shinta Dwi Prana Dewi, Moch Dzulkirom, D. A. (2015). System Analysis And Procedure Of Accounting For Sales And Cash Receipts In An Effort To Improve Internal Control. 3(1), 2015. Retrieved from researching.co,/en/

Suandi. (2019). The analysis of Public Satisfaction with Public Services Based on The Satisfaction of the Public in the District Office Belitang OKU Regency East. Journal PPS 
UNISTI, 1(2), 13-22. https://doi.org/10.48093/jiask.v1i2.8

Sukirman, S., Rosmiati, R., Alam, N., \& Kamal, K. (2020). System Design Information Yellow Card (Ak.1) To Job Seekers Office Of The Department Of Employment Of The City Of Makassar. ILTEK : Technology Journal, 14(2), 2067-2072. https://doi.org/10.47398/iltek.v14i2.418

Sukmasari, D. S. (2018). Implementation Of Administrative Services Academic Ikip Pgri Bojonegoro-Based Online. HE: Scientific Journal of Public Administration, 16(2), 1. https://doi.org/10.30996/dia.v16i2.1918

Trivena, S. M., Wijayanti, R. F., \& Evelina, T. Y. (2019). Analysis Of Administrative Procedure Of Cash Sales And Credit At Pt Sun Star Motor Malang In Order To Improve Internal Control. Adbis: Journal Of Administration And Business, 13(2), 184. https://doi.org/10.33795/j-adbis.v13i2.77

Wijaya, D., \& Irawan, R. (2018). Administrative Procedures Sales Bearing On The Business Jaya Teknika, Jakarta Barat. Perspective, XVI(1), 40. Retrieved from https://scholar.google.co.id/citations?view_op=view_citation\&hl=id\&user $=$ oWxuoc4A AAAJ\&citation_for_view=oWxuoc4AAAAJ:u-x6o8ySG0sC 